\title{
WAHDAT AL WUJUD DALAM PEMIKIRAN IBNU ARABI
}

\author{
A6d Halim Rofi'ie \\ Fakultas Hukum Universitas Brawijaya \\ Jl. MT Haryono No. 169 malang. Telp. 0341-582206 / 08585207475
}

\begin{abstract}
Ibnu Arabi, the Grand Master of Islam, is a great thinker whose controversial thought, wahdat al wujud, has significantly influenced the mystiques of Islam. The meaning of wahdat al wujud is basically two folds, i.e. that Being is the only One which exists and that the universe is merely a manifestation of the One. The One Being here refers to Allah SWT. The One covers up all the existing phenomena and functions as a resource which emanates the entire universe. In this context, He is referred to as al Haqiqat al Muhammadiyah. He might also be viewed as both the Universal Soul for His being the source of cosmos that governs the universe and the Universal Body for His reflecting any actions on every single micro existence that forms the universe. Furthermore, when His existence is deemed as a jauhar (jewel) that face-up any occurrences, He is typically known as al haba'. The concept of wahdat al wujud can actually be simplified into the principle of laa maujuda illa wujud al wahid (no existence except the Existing One, the Being). The One might reveal His own existence into different martabat or levels: Martabat Ahadiyah, Martabat Wahidiyah, and Martabat Tajalli Syuhudi. Those standing points trigger Ibnu Arabi to believe that any kinds of realities or existences are nothing but a true reflection of the One.
\end{abstract}

Ibnu Arabi, digelari al Syekh al Akbar, adalah salah seorang pemikir besar Islam yang pemikiran kontroversialnya, wahdat al wujud, telah membawa pengaruh besar dalam dunia mistik Islam. Maksud wahdat al wujud adalah bahwa Yang Ada hanyalah Wujud Yang Satu, semua alam semesta ini adalah manifestasi dari Yang Satu itu. Wujud Yang Satu itu adalah Allah Ta'ala. Yang Satu itu mencakup atas semua fenomena yang ada dan merupakan sumber daya akal yang memancar keseluruhan alam semesta. Dalam konteks ini Dia disebut al 
Hakekat al Muhammadiah. Yang Satu itu adalah sumber dari kosmos yang mengatur alam semesta, maka Dia disebut Jiwa Universal. Yang Satu itu menampakkan perbuatannya pada masing-masing wujud (mikro) yang ada di alam semesta, maka dia disebut dengan Tubuh Universal. Yang Satu itu bila dilihat dari keberadaan-Nya sebagai satu jauhar yang menghadap pada seluruh bentuk-bentuk kejadian maka dia berada dalam bentuk al haba'. wahdat al wujud adalah suatu konsep yang menyatakan bahwa "la maujuda illa al wujud al wahid" (Tidak ada yang maujud kecuali wujud yang Esa). Wujud yang mutlak ini menampakkan diri dalam tiga martabat, yaitu Martabat Ahadiyah, Martabat Wahidiyah, dan Martabat Tajalli Syuhudi. Ketiga poin pemikiran ini mendorong Ibnu Arabi untuk mempercayai bahwa berbagai bentuk kenyataan atau keberadaan tidak lain adalah bayangan sesungguhnya dari Yang Satu.

Key words: wahdat al wujud, the one (being), wujud (existence), martabat (levels)

\section{Pendahuluan}

Bila kita mengkaji filsafat mistis Ibnu Arabi, mungkin akan terlintas di benak kita, bahwa dalam beberapa hal ada kesesuaian konsep yang mirip yang dikemukakan oleh Ibnu Arabi dengan konsep-konsep Plotinus, Permanides dan filusuf lainnya. Di sinilah barangkali patut kita renungkan salah satu Haditst Nabi yang mengatakan bahwa "al hikmah" adalah barang berharga bagi seorang mukmin yang hilang. Maka barang siapa yang mendapatkannya hendaklah ia mengambilnya. Apakah al hikmah itu? Tulisan ini bukanlah dimaksudkan untuk menjawab pertanyaan tersebut, tetapi artikel ini hanya akan memaparkan tentang sebagian pemikiran Ibnu Arabi. Apakah ada relevansi antara al hikmah dalam Haditst tersebut dengan pemikiran Ibnu Arabi? Itu adalah soal kedua yang diharapkan menjadi bahan renungan dalam tafakkur dan tadabbur kita. Diamnya seorang mukmin adalah tafakkur sedang gerak lidahnya adalah dzikir. Sebelum membahas filsafat mistis Ibnu Arabi, maka terlebih dahulu kita mengenal pemikir besar ini yang juga sering dijuluki sebagai al Syaikh al Akbar.

\section{Mengenal Ibnu Arabi}

Syaikh Muhyi al Din Muhammad Ibnu Ali, umumnya dikenal sebagai Ibnu Arabi, dilahirkan di Murcia (sebuah kota di Spanyol Tenggara) pada tahun 560 H (1165 M). Dia dikenal di Barat sebagai Ibnu al Arabi, dan di Spanyol sebagai Ibnu Suraqa. Akan tetapi di Timur dia dikenal sebagai Ibnu Arabi tanpa "al" untuk membedakannya dengan Abu Bakar, seorang Qadi di Seville yang juga terkenal dengan sebutan Ibnu al Arabi (Husaini, 1977: 2). Ia 
keturunan dari suku Arab Tayy dan berasal dari keluarga yang saleh. Ayah dan kedua pamannya adalah sufi. Pada umur 8 tahun, Ibnu Arabi meninggalkan kota kelahirannya dan berangkat ke Lisbon. Di sana ia menerima pendidikan Agama Islam. Ia mengkaji al Quran dan Fiqih dari Syeikh Abu Bakar Ibnu Khalaf. Kemudian ia pindah ke Seville yang pada saat itu merupakan pusat Sufi di Spanyol, dan menetap di sana selama 30 tahun untuk mempelajari Haditst dan Ilmu Kalam serta Fiqih. Kemudian ia mengunjungi Kordova, di sana ia bersahabat erat dengan Ibnu Rusyd (Affifi, 1989: 92). Kemudian mengunjungi Tunisia pada tahun $1194 \mathrm{M}$, ia masuk aliran Sufi (Nasution, 1973: 92). Di Tunisia, Ibnu Arabi mempelajari karya Ibnu Qoyi Khal'anNa'layn, sebuah buku yang menurut Ibnu Khaldun seharusnya dibakar atau dicuci bersih gagasannya yang bid'ah (Schimmel, 1986: 272). Ibnu Arabi mempelajari karya-karya Ibnu Masarra dari Kordova yang membahas tentang cahaya yang menyucikan.

Pada tahun 1201 Ibnu Arabi mendapat ilham untuk melaksanakan ibadah haji ke Makkah. Di sana ia berjumpa dengan seorang wanita Persia muda yang sangat pandai. Tergugah oleh kecantikan dan kepandaian wanita itu ia menggubah Tarjuman al Ashwaq (Tafsir Kerinduan). Gubahan itu ditulis dalam tradisi persajakan Arab klasik yang indah. Ia kemudian menafsirkan sajak-sajaknya itu ke dalam pengertian mistik. Selanjutnya, ia melanjutkan perjalanan ke Kairo dan Konya lalu mengunjungi Baghdad dan akhirnya menetap di Damaskus. Di kota inilah ia dipanggil pulang ke rahmat Allah pada tahun $1240 \mathrm{M}$. Ibnu Arabi termasuk salah seorang pemikir besar Islam. Dante, seorang pemikir Eropa terpengaruh oleh pemikirannya. Asin Palacios mengemukakan bahwa pemikiran Ibnu Arabi juga berpengaruh kepada para sufi dan mistikus sesudahnya baik di Barat maupun Timur. Karena posisinya yang begitu tinggi dalam kalangan tasawuf, ia digelari dengan al Syekh al Akbar. Sebagian kaum skolastik Eropa seperti Raimond Lull mengenalnya dengan baik (al Ghonimi, 1985: 201).

Ibnu Arabi menulis sejumlah besar karyanya, di antaranya al Futuhat al Makkiah dan Fushush al Hikam, dua karya tersebut adalah karya yang paling mashur di antara karya-karya Ibnu Arabi. Muhammad Parsya, seorang pengikut Naqsabandiabad XV, membandingkan bahwa Fushush dengan jiwa dan Futuhat dengan hati (Schimmel, 1986: 273). Futuhat, seperti dijelaskan penulisnya, didiktekan oleh Tuhan melalui malaikat pemberi ilham, sedangkan Fushush, sebuah buku dengan dua puluh sembilan bab mengenai ilmu kenabian, diilhami oleh Nabi (Schimmel, 1986: 273). Prof. Dr. Harun Nasution mengemukakan 
bahwa Fushush al Hikam diterima keseluruhannya dari Nabi Muhammad dalam satu mimpi di tahun 626 H di Damaskus (Nasution, 1973: 92). Dalam kitab Fushush ini setiap faset membicarakan tentang kodrat kemanusiaan dan rohaniah dari seorang nabi tertentu, kodrat ini digunakan sebagai wahana segi tertentu dari ilmu pengetahuan illahi yang diwahyukan kepada nabi tertentu. Buku ini menjadi terkenal, sehingga para penyair dapat bermain-main dengan judulnya, seperti dilakukan oleh Maulana Abd al Rahman Jami ketika ia berbicara kepada kekasihnya: "Bila saja penulis faset-faset melihat bibirmu ia akan menuliskan seratus faset tentang ilmu Imam Mahdi".

\section{Konsep Wahdat Al Wujud}

Dalam membahas wahdat al wujud ini ada baiknya bila diungkapkan lebih dahulu tentang sistem pemikiran filsafat mistis Ibnu Arabi sebagai berikut:

1. Pemikiran tentang metafisika (Ma Ba'da al Thabi'ah).

Menurut Ibnu Arabi, Allah adalah awal ma'alim yang empat, yang tidak ada lagi suatu ma'lum dibelakangnya. Dia itulah yang disebut dengan al Wujud al Muthlaq, sebab keberadaannya tidak disebabkan oleh yang lain, dan wujudnya bukanlah selain Dzat-Nya itu sendiri (wa wujuduhu laisa ghoiru dzatihi).

Ma'lum kedua adalah hakekat universal yang ada pada Tuhan dan pada alam semesta. Hakikat ini bisa disebut qidam, bila yang dimaksud adalah yang maujud tanpa permulaan dan maujud tanpa ada yang mendahuluinya. Dan hakikat ini bisa disebut Haditst apabila yang dimaksud adalah yang maujud setelah kejadian yaitu apa-apa selain Allah Ta'ala.

Ma'lum ketiga adalah alam semesta yang terdiri dari apa-apa yang ada di bumi dan di langit dan apa-apa yang tercakup dalam keduanya selain manusia. Ma'lum keempat adalah manusia sebagai khalifah Allah di muka bumi yang juga disebut dengan alam kecil (mikro kosmos). Sedang tiga ma'alim sebelumnya disebut dengan alam besar (makro kosmos).

Hakekat universal bisa disebut alam juga bisa disebut bukan alam. Dan bisa disebut Tuhan (al Haq), juga bisa disebut bukan Tuhan (khalq). Keduanya satu tapi juga berbilang sesuai dengan jumlah bilangan individu di dalam alam. Tuhan telah ada ketika tak ada sesuatu pun bersamanya (kana Allah wa lam yakun ma'ahu syaiun ghoiruhu). Kemudian bisa berkehendak untuk mewujudkan alam dalam suatu bentuk yang telah ada di dalam ilmu-Nya. Dengan kehendak ini terciptalah suatu hakekat yang disebut al haba', dan itulah maujud pertama yang ada dalam alam yang oleh para filosof disebut 
hayula. Maujud pertama ini adalah suatu alam yang ada disebabkan oleh suatu daya (al quwwah al shalahiah), dan dari daya itu keluarlah perbuatan (al fi'il) yang berproses melalui suatu urutan sampai mencapai kesempurnaan. Semua bentuk-bentuk alam menerima cahaya Allah sesuai dengan kapasitas persiapannya, mirip dengan penerimaan cahaya bagi suatu pojok rumah yang datang dari sumber cahaya (siraj), semakin dekat ke siraj semakin banyak dia menerima cahaya.

Al haba' yang paling dekat dengan nur Allah adalah hakikat Muhammad SAW yang disebut dengan Aql, dialah sayyid al alam yang mencakup segalanya, dan dialah yang pertama-tama nampak dalam wujud, kemudian nampaklah maujud-maujud lainnya secara berantai sesudah itu dan berurutan dari yang paling tinggi sampai yang paling rendah.

Wujud itu terdiri dari empat macam yaitu:

a. Allah.

b. Akal Universal yang juga disebut al Haqiqat al Muhammadiah.

c. Jiwa Universal yang beremanasi kepada seluruh jiwa.

d. Tubuh Universal juga disebut al haba'/hayula.

Alam ini adalah qadim karena ia telah maujud dalam satu ilmu Allah yang qadim, dan alam ini Haditst karena ia berada pada suatu bentuk yang tadinya belum ada kemudian ada. Bisa juga dipahami, bahwa alam ini qadim dalam konteks keberadaannya ketika masih berwujud hakikat universal, dan alam ini Haditst dalam konteks bentuk fenomenalnya yang bermacam-macam. Di dalam kitab Fushush al Hikam disebutkan:

"Sesungguhnya wujud itu ada yang azali dan ada yang tidak azali (Haditst). Yang azali adalah wujud al Haq karena diri-Nya sendiri, dan yang tidak azali adalah wujud al Haq dalam bentuk alam yang tetap. Maka dinamakan Haditst karena dia nampak sebagiannya terhadap sebagian yang lain, dan Dia nampak karena diri-Nya sendiri dalam beberapa bentuk alam semesta".

Dr. Muhammad Yusuf Musa di dalam bukunya Falsafat al Akhlaq Fi al Islam mengatakan: "Jika pendapatnya (Ibnu Arabi) tentang alam adalah demikian, yaitu satu yang qadim dilihat dari segi hakikatnya, dan banyak muhdats dilihat dari segi bentuk manifestasinya ... maka filusuf kita (Ibnu Arabi) dalam hal ini tidak berbeda dengan para pengikut Asy'ari yang menyatakan bahwa alam ini semuanya semisal dengan satu jauhar dan berbeda-beda dalam bentuk-bentuk aradz-nya, atau dengan kata lain "satu hakekatnya tapi berbeda 
bilangan bentuk dan gambarnya" (Musa, 1963: 248).

\section{Filsafat Wahdat al Wujud}

Maksud wahdat al wujud adalah bahwa Yang Ada hanyalah Wujud Yang Satu, semua alam semesta ini adalah manifestasi dari Yang Satu itu. Wujud Yang Satu itu adalah Allah Ta'ala. Yang Satu itu mencakup atas semua fenomena yang ada dan merupakan sumber daya akal yang memancar keseluruhan alam semesta. Dalam konteks ini Dia disebut al Hakekat al Muhammadiah. Yang Satu itu adalah sumber dari kosmos yang mengatur alam semesta, maka Dia disebut Jiwa Universal. Yang Satu itu menampakkan perbuatannya pada masing-masing wujud (mikro) yang ada di alam semesta, maka dia disebut dengan Tubuh Universal. Yang Satu itu bila dilihat dari keberadaanya sebagai satu jauhar yang menghadap pada seluruh bentuk-bentuk kejadian maka dia berada dalam bentuk al haba'.

Dengan bahasa yang ringkas, wahdat al wujud adalah suatu konsep yang menyatakan bahwa "la maujuda illa al wujud al wahid". Artinya: "Tidak ada yang maujud kecuali wujud yang Esa", dan Yang Esa itu berbilang sejumlah bilangan ta'ayyunat. Akan tetapi berbilangnya itu tidaklah berarti menjadikanNya berbilang dalam Dzat yang wujud itu, sebagaimana berbilangnya jumlah manusia juga tidak berarti bahwa hakikat manusia itu berbilang (Musa, 1963: 248).

Dalam satu paham wahdat al wujud, Nasut yang ada dalam hulul diubah oleh Ibnu al Arabi khalq dan lahut menjadi haq, khalq dan haq adalah dua aspek bagi tiap sesuatu. Aspek yang sebelah luar disebut khalq dan aspek yang sebelah dalam disebut haq. Kata-kata khalq dan haq merupakan sinonim dari al ardh dan al jauhar, dan sinonim dari al dhahir dan al bathin. Menurut paham ini tiap-tiap yang ada mempunyai dua aspek. Aspek luar yang merupakan al ard dan khalq yang merupakan sifat kemakhlukan dan aspek dalam yang merupakan jawhar dan haq yang mempunyai sifat ketuhanan. Filsafat wahdat al wujud ini timbul dari paham bahwa Allah ingin melihar diri-Nya di luar diri-Nya dan oleh karena itu dijadikan-Nya alam ini (sesuai dengan Haditst "kuntu kanzan makhfiyan faahbabtu an u'rafa fa khalaqtu al khalqa fihi arofuni"), maka alam ini merupakan cermin bagi Allah. Dikala Ia ingin melihat diri-Nya, Ia melihat kepada alam, pada benda-benda yang ada di alam. Karena dalam tiap benda itu terdapat sifat ketuhanan, Tuhan melihat diri-Nya. Dari sini timbul paham kesatuan. Yang ada dalam alam ini kelihatannya banyak, tetapi sebenarnya itu hanya satu. Tak ubahnya hal ini sebagai orang yang melihat dirinya, dalam 
beberapa cermin yang diletakkan di sekelilingnya. Di dalam tiap cermin ia lihat dirinya, dalam cermin itu dirinya kelihatan banyak, tetapi dirinya sebenarnya dirinya hanya satu (Nasution, 1973: 57) Seperti dijelaskan al Qashani: "wajah sebenarnya satu, tetapi jika engkau perbanyak cermin, ia menjadi banyak".

Permanides berkata: "Yang ada itu Satu, yang banyak itu tidak ada. Yang kelihatan banyak dengan panca indera adalah ilusi".

Dengan bentuk lain, filsafat ini bisa dijelaskan sebagai berikut: Makhluk dijadikan dan wujudnya bergantung pada wujud Tuhan, sebagai sebab dari segala yang berwujud selain Tuhan. Yang berwujud selain Tuhan tidak akan mempunyai wujud, sekiranya Tuhan tidak ada. Tuhanlah sebenarnya yang mempunyai wujud hakiki. Yang dijadikan hanya mempunyai wujud yang bergantung pada wujud diluar dirinya yaitu Tuhan. Dengan demikian yang mempunyai wujud sebenarnya hanyalah Tuhan dan wujud yang dijadikan ini pada hakikatnya bergantung pada wujud Tuhan. Yang dijadikan sebenarnya tidak mempunyai wujud. Yang mempunyai wujud sebenarnya hanyalah Allah. Dengan demikian hanya ada satu wujud, yaitu wujud Tuhan. Wujud selain dari wujud Tuhan adalah wujud bayangan (Nasution, 1973: 95).

Untuk lebih mempertajam pemahaman kita tentang wahdat al wujud ini ada baiknya kita ikuti ulasan AE Affifi (1989) berikut:

Menurut Ibnu Arabi, hanya ada satu realitas dalam eksistensi. Realitas ini kita pandang dari dua sudut yang berbeda, pertama kita namakan haq, apabila kita pandang haq itu sebagai Essensi dari semua fenomena dan kedua khalq, apabila kita pandang sebagai fenomena yang memanifestasikan Essensi itu. Haq dan halq, Yang Satu dan Yang Banyak hanyalah nama-nama untuk dua aspek subjektif dari satu realitas, ia adalah satu kesatuan nyata tapi ragam dalam empiris. Realitas ini adalah Tuhan. Ibnu Arabi berkata: "Apabila engkau pandang Dia melalui Dia, maka kesatuan itu menghilang".

Doktrin Plotinus menyatakan bahwa Yang Maha Esa itu ada di manamana dan tidak di mana-mana. Menurut AE Affifi (1989), Ibnu Arabi menggaungkan kembali doktrin Plotinus tersebut tetapi keduanya berbeda. 'Yang Satu'nya Plotinus ada di mana-mana sebagai suatu sebab, sedang 'Yang Satu'nya Ibnu Arabi ada di mana-mana sebagai suatu Essensi, dan tidak di mana-mana sebagai Essensi Universal.

Di dalam sajaknya, Ibnu Arabi menulis:

"Dia puja-puji saya dan saya puja-puji Dia.

Dan Dia sembah saya dan saya sembah Dia.

Dalam satu keadaan saya akui Dia.

Dan di dalam a'yan saya tolak Dia. 
Dia tahu saya dan saya tidak ketahui Dia.

Dan saya ketahui Dia dan pandang Dia” (Affifi, 1989: 28). berikut:

Dalam gubahan puisinya yang lain, Ibnu Arabi menulis sebagai

Bila mana Kasihku tampak

Dengan mata apa aku melihat Dia?

Dengan mata-Nya, bukan dengan mataku.

Karena tak seorangpun melihat-Nya, kecuali Dia sendiri (Schimmel, 1986: 274).

Di dalam Fushush al Hikam, Ibnu Arabi berkata:

"Kita untuk Dia seperti argumen yang kita tetapkan dan kita untuk kami.

Tidak ada bagi-Nya selain kejadianku, maka kita bagi Dia seperti kita bersama kami.

Maka aku punya dua wajah, Dia dan aku, dan tidak ada bagi-Nya aku dengan Aku.

Akan tetapi dalam diri saya tampak Dia, dan kita bagi Dia semisal aku”.

Ikut melengkapi uraian tentang wahdat al wujud ini, penulis ringkaskan dari tulisan yang ditulis oleh Zainun Kamal MA sebagai berikut:

Ibnu Arabi mengatakan bahwa wujud ini pada hakekatnya adalah satu, yakni wujud Allah yang Mutlak. Wujud yang mutlak ini menampakkan diri dalam tiga martabat yaitu:

a. Martabat Ahadiah

Dalam martabat ini, wujud Allah merupakan Dzat yang mutlak, tidak bernama dan tidak bersifat. Tuhan berada dalam keadaan murni ('ama'), kedalaman yang mutlak. Yang ada hanya dzat semata. Dalam martabat ini, Allah tidak sesudah, tidak sebelum, tidak di atas, tidak di bawah, tidak bagaimana, tidak di mana, tidak kapan, dan Dia sekarang sebagaimana adaNya. Dia tidak tersusun dari isim musamma, karena isim-Nya adalah Dia dan musamma-Nya adalah Dia.

b. Martabat Wahidiah

Dalam martabat ini, Dzat itu menampakkan diri (bertajalli) melalui sifat dan asma. Dengan tajalli ini, Dzat tersebut dinamakan Allah sebagai pengikat sifat-sifat dan asma-asma yang indah (al asma al husna). Akan tetapi sifat dan asma tersebut pada suatu sisi identik dengan Dzat Allah sendiri. 
Di tengah-tengah antara ahadiah dan wahidiah ada penghubung yang disebut A'yan Tsabitah. A'yan Tsabitah ini mempunyai ciri wujud yang unik, yaitu aktif dan pasif. Pasif karena ia menerima pelimpahan dari Yang Esa, dan aktif karena hubungannya dengan objek-objek fenomena.

c. Martabat Tajalli Syuhudi

Dalam martabat ini Allah bertajalli melalui asma dan sifat-Nya dalam kenyataan empiris. Dengan firman-Nya "kun", maka A'yan Tsabitah yang dulunya merupakan wujud potensial dalam Dzat Ilahi, kini menjadi kenyataan aktual dalam berbagai citra alam empiris.

Demikianlah penjelasan tentang wahdat al wujud dan masih banyak pikiran Ibnu Arabi yang lain yang di antaranya adalah konsep tentang agama universal.

d. Ibnu Arabi Tentang Agama Universal

Konsep tentang wahdat al wujud ini bila diaplikasikan pada satu bentuk agama, maka bentuk agama itu adalah agama universal. Menurut sistem pemikiran ini, semua jalan mengarah kepada satu jalan lurus menuju Tuhan. Dari bentuk keberhalaan yang paling kasar sampai filsafat keagamaan yang paling abstrak, akan dijumpai kepercayaan-kepercayaan yang mengarah kepada Tuhan. Perbedaan antara monotheisme dan politheisme serta kepercayaan-kepercayaan yang lain, terletak pada logika antara "Yang Satu" dan "Yang Banyak". Kegagalan politheisme terletak pada ketidaksadaran si politheis tentang adanya realitas kesatuan mutlak dari keseluruhan, lalu ia memandangnya sebagai wujud yang dapat dibagi-bagi. Dalam kenyataannya, tidak ada sekutu bagi Tuhan, sebab Dia adalah 'Ayn dari segala sesuatu yang disembah dan sebenarnya tidak ada yang disembah kecuali Dia. Ibnu Arabi tidak menolak politheisme, asalkan para penyembah patung-patung dan gambar-gambar itu benar-benar menyadari bahwa di belakang bentuk-bentuk Tuhan mereka itu terdapat Realitas Yang Esa, dan memandang bentuk-bentuk berhala itu hanya sebagai manifestasi (wujuh) dari realitas ini, dan sadar pula bahwa berhala yang dibuat-buat itu kosong tidak ada apa-apanya.

Bentuk-bentuk kepercayaan kepada Tuhan itu beragam menurut nature dari obyek-obyek kepercayaan itu, dan kepercayaan apapun yang mengurangi keuniversalan mutlak dari Tuhan itu adalah parsial dan tidak sempurna. Menyembah bintang atau pohon, artinya menyembah suatu Tuhan yang merupakan suatu manifestasi parsial dari Tuhan yang nyata. Tetapi menyembah Dia dalam semua bentuk, artinya menyembah Allah yang merupakan satu-satunya objek tulen dari sesembahan itu. Tiap orang itu benar dalam keyakinannya, 
tak peduli apapun parsialnya kepercayaan itu, namun tetap salah bila objek kepercayaannya itu bukan Allah. Hanya orang-orang sufilah yang benar-benar menyembah Tuhan sejati, yang asma-Nya (Allah) adalah paling universal dari semua nama-nama Tuhan. Kepercayaan para filusuf kurang pas karena menyatakan Tuhan dalam transendensi murni, begitu pula kepercayaan orang politheis juga kurang mengena karena menyatakan Tuhan dalam immanensi murni. Padahal transendensi saja, atau immanensi saja tidak dapat menjelaskan nature dari realitas itu sepenuhnya. Satu-satunya agama yang tepat menurut Ibnu Arabi adalah agama universal yang mencakup semua agama-agama, yang ia identifikasikan dengan "Islam", tapi bukanlah Islamnya Muhammad SAW yang monotheistik. "Islam" bagi Ibnu Arabi bukan hanya agama Muhammad SAW, tapi mencakup semua agama dan kepercayaan.

Ibnu Arabi berpendapat bahwa cinta adalah basis bagi semua bentuk penyembahan. "Menyembah" artinya mencintai obyek yang disembah. Cinta adalah suatu prinsip yang meresapi semua wujud dan mengikat meraka bersama. Cinta adalah universal walaupun nampak multisiplitas dalam bentuk-bentuknya. Cinta adalah essensi Kudus itu sendiri. Oleh sebab itu objek tertinggi dan terbenar dari penyembahan di mana Tuhan itu disembah adalah cinta (Affifi, 1989: 107). Berikut ini penulis paparkan salah satu gubahan Ibnu Arabi:

Dulu tidak kusenangi temanku
Jika agamanya lain dari agamaku
Kini kalbuku bisa menampung semua
Ilalang perburuan kijang atau biara pendeta
Kuil pemuja berhala atau Ka'bah haji berdatangan
Lauh Taurat atau Mushaf Al Quran
Kupeluk agama Cinta, kemampuan yang kutuju
Kendaraanku cinta, ialah agamaku dan imanku (al Ghanimi, 1985: 205).

Demikianlah Ibnu Arabi dalam memandang agama, dilihat dari filsafat wahdat al wujudnya dan ada pemikiran yang masih berkaitan dengan filsafat tersebut yaitu konsep tentang Insan Kamil.

\section{Simpulan}

Mungkin kita tersentak untuk sementara waktu dalam memahami filsafat mistisnya Ibnu Arabi. Namun, sebaiknya tidak perlu cepat-cepat menghakimi, karena hakim yang adil hanyalah Allah SWT. Ilmu Tuhan sangatlah luasnya, 
andaikan seluruh air lautan dijadikan tinta untuk menuliskan ilmu Tuhan, niscaya akan keringlah air lautan itu sebelum ilmu Tuhan itu sendiri habis. Dengan menyadari kedhaifan diri dan sadar pula bahwa wa ma utitum min al ilmi illa qalila akan tersibaklah suatu realitas bahwa Allah itu Maha Agung lagi Maha Mengetahui. Hadana Allah ila shirathihi al mustaqim.

\section{Daftar Pustaka}

Affifi, AE. 1989. A Mystical Philosophy of Muhyi al Din Ibnu Arabi. Jakarta: Gaya Media Pratama.

Al Ghanimi, Abu al Wafa. 1985. Madkhal ila al Tashawwuf al Islam. Terjemahan oleh AR Ustmani. Bandung: Pustaka.

Arabi, Ibnu. 1980. Fushush al Hikam. Bairut: Dar al Kitab al Arabi.

Nasution, Harun. 1973. Filsafat dan Mistisisme Dalam Islam. Jakarta: Bulan Bintang.

Husaini, Moulvi SAQ. 1977. Ibnu al Arabi. Lahore: SHM Ashraf.

Musa, M. Yusuf. 1963. Falsafat al Akhlaq fi al Islam. Kairo: Muassasah al Khanji.

Schimmel, Annemarie. 1986. Mystical Dimension of Islam. Terjemahan oleh Supardi Djoko dkk. Jakarta: Pustaka Firdaus. 